\title{
Social Determination of Living Conditions in Post-Communist Societies*
}

\author{
PÉTER RÓBERT ** \\ Social Science Informatics Center (TÁRKI), Budapest
}

\begin{abstract}
Living conditions have played a special role in most of the former communist societies. After World War II, living conditions were controlled by the communist equality principle, while in the following decades living conditions improved and took on the role of legitimating the communist system. In this article we investigate the inequalities in living conditions in six post-communist societies (Bulgaria, Czech Republic, Hungary, Poland, Russia, and Slovakia). The data are taken from the 1993 comparative survey Social Stratification in Eastern Europe after 1989, conducted by Iván Szelényi and Don Treiman.

Living conditions are operationalised from the viewpoint of material and cultural consumption. Separate measurements were constructed for both of these dimensions and present a typology of living conditions: (1) high material and high cultural living conditions; (2) high material and low cultural living conditions; (3) low material and high cultural living conditions; and (4) low material and low cultural living conditions.

A causal analysis is performed where to investigate the social determination of belonging to different types of living conditions, applying multinominal logistic regression. Social and demographic characteristics of respondents (occupation, education, income, informal economy participation, gender, age, residence) and also 'accumulated' social assets from 1988 such as informal economy participation and party membership are used as predictor variables. Analyses are run separately for the six countries for presenting the country specific differences in the determination of living conditions.
\end{abstract}

Czech Sociological Review, 1997, Vol. 5 (No. 2: 197-216)

\section{Introduction}

In this paper I analyse living conditions operationalised by cultural and material consumption in six post-communist countries: Bulgaria, Czech Republic, Hungary, Poland, Russia and Slovakia. Living conditions comprise a broad concept in sociological research. The theoretical ground for making distinctions between expressions such as 'way of life' or 'lifestyle' can be based on the allocation of resources in respect of money and time. Two types of resources can be distinguished: financial and temporal. The resources

\footnotetext{
*) Previous versions of this paper were presented at the semi-annual meeting of ISA RC28, Stockholm, May 1996 and at the Research Seminar of Humboldt Universität, Berlin, November 1996. I appreciate the comments of the participants of these meetings. I also acknowledge Matild Sági for the multinomial logistic regression estimates I use in the analysis. This article was prepared at the Netherlands Institute for Advanced Studies, NIAS, when I was holding a Magyar-Fellowship between February 1 - June 30, 1997.

${ }^{* *}$ ) Direct all correspondence to: Dr. Péter Róbert, PhD., Social Science Informatics Centre (TÁRKI), Victor Hugo u. 18-22, H-1132 Budapest, Hungary, phone + 3611497531 , fax + 361 1290 470, e-mail robert@tarki.hu
} 
connected to income and time can be divided into a constrained and a discretionary part, taken from the perspective of the Maslowian hierarchy of human needs [Maslow 1954]. Both financial and temporal resources have a constrained part on the bottom of the hierarchy used for ensuring the basic needs of nutrition, accommodation and physical safety. On the higher level, the discretionary part of resources serves for covering further needs influenced by choice, value orientation and individual preferences. Accordingly, living conditions have a constrained part which is closer to the term 'way of life' suggesting a higher degree of objectivity and conditionality; and a discretionary part which is closer to the term 'lifestyle' with a connotation more strongly associated to individual choices and values.

The use of cultural and material consumption patterns is frequently used in sociology for investigating living conditions. This approach expresses that living conditions are based on goods which are available on the market, people decide to buy them or not, or decide what to buy among a variety of 'functional equivalents' which serve the purpose of covering the same needs. From a theoretical perspective, Weber's multidimensional stratification approach is to be referred to in this respect, which is based on consumption groups and their similarities or differences in prestige [Weber 1966]. Veblen's study on leisure class is another point of reference. He emphasised the importance of the visibility of living conditions and introduced notions like 'conspicuous leisure', 'conspicuous consumption' and 'prestige consumption' [Veblen 1931]. In his more recent studies, Sobel [1981, 1983] also operationalises lifestyle by consumption. Collins [1979] speaks about cultural market, cultural currency and cultural ties forming a link which helps social groups represented by a given visible lifestyle to recognise each other. Bourdieu goes one step further and states that the possession or lack of cultural capital influence schools success in meritocratic societies [Bourdieu 1973, Bourdieu and Passeron 1977]. Nevertheless, when Bourdieu attempts to find empirical support for his theory, he also uses lifestyle measures manifested by cultural consumption or attributes connected to tastes, aesthetics and habits.

Bourdieu [1984] proposes another model of lifestyle of a multi-dimensional character. According to his concept, lifestyle has both an economic and a cultural dimension (which, of course, are correlated), through which the status hierarchy becomes doubled. Those without enough discretionary time and income to be able to maintain a lifestyle based on values, tastes, aesthetics and other preferences are found on the bottom of society. On higher societal levels, groups appear which are able to make lifestyle decisions related to their preferences. In the economic dimension the hierarchical order goes from unskilled labourers to managers and wealthy entrepreneurs, while in the cultural dimension it goes from the same unskilled labourers to university professors and artists. The decisions these groups make concerning their lifestyle are manifested in their relationship with art, in their taste, in use of discretionary time, in clothing, eating habits, housing, and so forth.

In this paper, I first present an overview of previous researches and the role of living conditions under and after communism. This section provides the basis for the hypotheses. The empirical part of the paper begins with a description of the data and measurements of dependent and independent variables. The results are then presented and discussed. 


\section{Living Conditions Under and After Communism}

Living conditions played an ideological role in the former communist societies. Communist leaders placed great emphasis on physical and psychological safety, namely that workers need not be afraid of losing their job, that their salary was sufficient to cover their needs in respect of basic nutrition and clothing, and that they receive housing from the state. Equality of consumption was a basic principle in the 1950s and 1960s in communist societies. Since market relations were destroyed in the economy and planning regulations were applied, the communist governments were able to keep the consumer prices of housing, clothing, nutrition, etc. low irrespective of the real costs of production. In accordance with equal opportunities in education, it was an ideological goal to make theatre performances, exhibitions in museums, concerts or libraries available to the broadest possible audience of working people. Prices for cultural consumption were also kept artificially low, thus financial circumstances had little influence on cultural participation.

In the 1970s market relations began to emerge in some communist countries, for example, Hungary and Poland as did the appearance of inequalities consumption. Material consumption and the possession of consumer goods became prestigious and a means of attaining 'visible success' (Sobel's term). Living conditions gradually improved everywhere under socialism and communist leaders used this fact for legitimating the system. This mechanism worked most effectively in Hungary, was present in Czechoslovakia and Poland to some degree, and was much less observable in Bulgaria or Russia.

The new legitimating role of living conditions became reflected by sociological research. In the Soviet Union more than 100 works had been published on 'way of life' by 1976 [Siciński 1978: 9]. These researches were supported by the official ideology. Since leisure time gradually increased under socialism, party officials wanted to know more about the 'utilisation of free time', that is the activities of working people in the time when they were not working [e.g. Szántó 1972]. Another political item on the agenda of this research was to prove the "levelling out of big class differences and the rise in the living standard of the broad mass of people" [Filipcova 1972: 6]. Research on culture was expected to prove that the so-called 'cultural monopoly' of the former ruling classes had been abolished under socialism and that the cultural knowledge and interest of the working class had substantially increased [e.g. Vitányi 1978]. For a better 'registration' of way of life, time budget surveys were 'invented' by Alexander Szalai in Hungary at this time. The method was later developed into a tool of comparative research on living conditions [Szalai 1972, Szalai and Andrews 1980].

While some investigations into way of life took an approach with strong psychological, philosophical or ideological aspects [Siciński 1974; Mansurov, Yadov et al. 1974; Gheliuta and Gogoliukhin 1974], others were better connected to stratification research presenting also empirical findings [Wesołowski 1970, Machonin 1970, Szántó 1977, Siciński 1978]. The introduction of multidimensionality and the concept of status inconsistency [Lenski 1954] strengthened the link between stratification and lifestyle research [Machonin 1970]. The relation of status inconsistency and social inequalities was also discussed at that time in Polish sociology [Wesołowski and Słomczynski 1983]. In the 1980s, Kolosi [1984] carried out a stratification model survey in Hungary using this approach. In his research, cultural lifestyle turned out to be the most important status dimension determining social position. In the consumption model of Utasi [1984], the 
majority of Hungarians were characterised by a certain kind and degree of inconsistency in respect of living conditions. Perhaps the most important thing to be learned from these empirical works is that inconsistency influences living conditions under socialism and the category of 'stylistic unity' as introduced by Sobel [1983] cannot be applied for these societies.

Previous studies also proved that the ideological goal of equality in cultural and material consumption was not fulfilled. The empirical test of Bourdieu's cultural capital hypothesis - following the earlier works by DiMaggio [1982], DiMaggio and Mohr [1985] or De Graaf [1986] - indicated that cultural lifestyle is an important intervening variable of status attainment models, a significant channel for the reproduction of social inequalities under communist conditions [Róbert 1984, 1990; Kolosi 1987; Mateju 1990; Ganzeboom, De Graaf and Róbert 1990]. In a recent analysis on income determination Böröcz and Southworth [1996] found that measurements for cultural capital and habitus influenced even earnings over and above the level of formal education.

In a comparative perspective, using Hungarian, Czechoslovakian and Dutch data, Kolosi [1990] found that, on the one hand, social origin determines both cultural and material lifestyle, on the other hand, there is an indirect influence where education and income play the role of intervening variables. Using data from the same three countries, the results of De Graaf [1991] demonstrated that the better educated member of the family has the greater influence on the family's consumption (status maximalisation effect). $\mathrm{He}$ also found that status inconsistency affects material consumption. In the case of high income and low education (over-rewarded position) material consumption increases; while the low income and high education combination (under-rewarded position) leads to a lower level of material consumption.

All previous studies in the field referred to above show that living conditions have not been independent of various sociological determinants in the former communist societies. There is no reason to assume that this association, which was obviously present in the 1970s and 1980s, has disappeared during the course of transformation. In fact, emerging market principles, i.e. the abolition of the former state subsidies on consumer goods as well as of cultural leisure time activities may practically result in an increase in prices. The social consequences of this process in respect of material and cultural consumption are contradictory - at least for Hungary. The available survey data (taken from TARKI's Data Archive from 1982 and 1986) indicate an increase in the possession of various consumer durables such as automatic washing machines, colour televisions, freezers, microwaves, VCRs, PCs, and so on. Central Statistical Office data also display the same trend: for example, colour televisions were present in $23 \%$ of households in 1986 as compared with $71 \%$ in 1993; ownership of automatic washing machines was $25 \%$ of households in 1986 as against 40\% in 1993 [Harcsa 1994].

Changes are more unfavourable in respect of cultural participation. Both data from earlier Hungarian stratification and lifestyle surveys and data from the recent time budget surveys reveal a decline in time spent visiting theatres, museums or reading books and newspapers [Falussy and Zoltánka 1994]. Previous time budget surveys also showed that Hungarians spent more time on work and money-making activities than citizens of other European nations [Adamczuk, Andorka et al. 1988], indicating that Hungarians were ready to devote their discretionary time to earning discretionary money. This process may 
be stronger in Hungary as compared to the other post-communist societies because subsidies in the cultural field have probably been withdrawn here to a higher degree.

\section{Hypotheses}

It is assumed that living conditions are highly stratified in the post-communist societies. In addition we expect that living conditions are not crystallised (to use Lenski's expression) and a large proportion of citizens in these countries have to 'choose' between cultural and material lifestyle because they cannot 'afford' both. Following certain traditions of stratification research [Machonin 1970, Wesołowski and Słomczynski 1983, Kolosi 1984] the inconsistent character of living conditions under post-communism are going to be taken into consideration. The belief is that a certain proportion of the population in these societies have only constrained financial and temporal resources and have no options as regards their living conditions. Another proportion of the population have more financial and temporal resources but are 'forced' to decide how to use the discretionary part of their resources. This choice will result in inconsistent living conditions in either the cultural or material respect. Finally, a part of the population have enough financial and temporal resources to afford consistent living conditions in terms of both cultural and material assets.

In the social determination of living conditions, social status as measured by income, education and class position is expected to have an impact. Since market relations are still underdeveloped in post-communist societies, the various forms of informal economy participation can indicate the possession of special ambitions, skills and capabilities. These activities may also affect living conditions significantly. In respect of demographic features some gender differences are expected and it is assumed that a younger age and urbanised place of residence have positive effect on better living conditions. Present living conditions are expected to be influenced by economic market-related assets or political assets from the period before 1989. During the egalitarian communist era differences between official salaries were not too high, the redistribution system was the main source of inequalities, but individuals and families were able to participate in the informal economy. These activities are even stronger indicators of market-related ambitions and capabilities before 1989 than in the present. Previous Communist Party membership represents a political asset, a favourable position in the redistribution system being useful even for present living conditions.

It is anticipated that the influence of income will vary by the type of living conditions. It will be smaller for cultural rather than material consumption and it will be the strongest for the type of both cultural and material lifestyle. Conversely, education is assumed to be stronger for cultural than material consumption. Based on Bourdieu's work on distinction of cultural and economic lifestyle, a stronger impact of self-employment on material assets and a stronger effect of service classes on cultural activities is assumed. The impact of informal economy participation should be stronger for material assets. Since this activity is time consuming, it may even have a negative impact on cultural consumption. Informal economy participation before 1989 will especially influence the level of material assets. It can be expected that gender differences in favour of women can be found especially for cultural consumption. The influence of a higher level of urbanisation will be stronger for cultural lifestyle. Moreover, Communist Party membership will have an impact especially on the living conditions of those who combine cultural and material assets. 
In respect of country variation, living conditions are expected to be at a higher level in Hungary, Poland and Czech Republic as compared to Slovakia, Bulgaria and Russia. The general pattern of social determination may be quite similar for sociodemographic effects. Income may influence living conditions rather more strongly in Hungary than in the other post-communist societies because prices for both material and cultural consumption have increased there to a larger degree. Urban-rural differences in determining living conditions may be larger in Russia and Bulgaria when compared to the other four post-communist societies. For informal economy participation a more marked country-specific variation should be seen. Since the informal economy flourished mainly in Hungary and Poland, it will matter more for these countries, - especially when measured for the period before 1989. Finally, for Communist Party membership a stronger impact for Bulgaria and Russia is anticipated where communist redistribution was stronger than in other countries.

\section{Data and Measurements}

The survey data of 'Social Stratification in Eastern Europe after 1989' (the principal investigators were Iván Szelényi and Donald Treiman, UCLA, USA) were used for the analysis. Six transition societies (Bulgaria, Czech Republic, Hungary, Poland, Russia and Slovakia) were involved in the survey, the field work was carried out in 1993. All previous information on respondents are of a retrospective character. More than 4500 adult people (aged between 18 and 60) were interviewed face-to-face in each of the countries involved.

For the analysis a dependent variable containing four categories was developed indicating whether the respondent has only material assets, or only cultural assets, or both, or none. The categorisation is based on the fact of whether the respondent has a higher or lower score on the scales measuring material or cultural living conditions compared to his/her country specific average. The independent variables contain measurements for social status (income, education, occupation, labour force participation), demographic position (gender, age, place of residence), informal economy participation in the present and past, and political participation under the communist regime (see details in the appendix).

\section{Results}

Table 1 presents the typology for living conditions, the dependent variable of the analysis. Since the distributions are based on country-specific calculations the percentages cannot be compared one by one row-wise but the pattern displayed by the typology can be interpreted. The distributions are based on normalised values of material possessions and cultural participation and they are also relative in the sense that the country specific means have been used as cutting points.

The strongest inequalities in living conditions can be observed for Hungary where the distribution is the most polarised. Every fourth respondent is above the countryspecific average in both material and cultural respects, while almost every second respondent scores under the average. The 'consistent uppers' are of a similar magnitude in Poland and Slovakia and are only somewhat smaller in the other three countries. The proportion of 'consistent lowers' is about the same in Bulgaria and Hungary, only somewhat smaller in Poland and Slovakia and much smaller in Czech Republic and Russia. The inconsistent - cultural or material - 'middles' also indicate a characteristic pattern for 
these societies: those with cultural activities always form a larger group (with the exception of Poland where the difference in distribution is very small).

Estimates of causal analysis on the typology of living conditions are shown in Table 2a-2c. ${ }^{1}$ The explanatory power of the models vary between $11 \%$ for Czech Republic, Russia and Slovakia and 21\% for Bulgaria, Hungary and Poland.

Table 1. Living conditions typology by countries (\%)

\begin{tabular}{lcccccc} 
Typology & $\begin{array}{c}\text { Bulgaria } \\
(3326)\end{array}$ & $\begin{array}{c}\text { Czech Rep. Hungary } \\
(3808)\end{array}$ & $\begin{array}{r}\text { Poland } \\
(3079)\end{array}$ & $\begin{array}{r}\text { Russia } \\
(3616)\end{array}$ & $\begin{array}{r}\text { Slovakia } \\
(4066)\end{array}$ \\
\hline Above the average & 19.3 & 20.4 & 25.1 & 23.6 & 19.1 & 22.7 \\
Cultural activities & 21.5 & 26.6 & 17.9 & 19.7 & 25.6 & 24.4 \\
Material assets & 11.6 & 17.6 & 13.7 & 17.0 & 18.7 & 14.7 \\
Below the average & 47.6 & 35.4 & 43.3 & 39.7 & 36.6 & 38.2 \\
Total & 100.0 & 100.0 & 100.0 & 100.0 & 100.0 & 100.0 \\
\hline
\end{tabular}

Source: Stratification in Eastern Europe after 1989 survey

Diverse types of living conditions are differently influenced by the basic status variables: income, education, labour force participation, and class. Income seems to have a moderate impact on living conditions. Cultural consumption is not influenced by financial situation (if it is controlled for the other predictor variables). Income has a significant effect only for Hungary. At the same time, it affects the other two types of living conditions somewhat more strongly. Income has the largest influence on living conditions in Hungary and Poland.

1) The main analytical tool applied in the paper is multinominal logistic regression. This method performs maximum-likelihood estimation of models with discrete dependent variable. The explanatory variables can be either discrete or continuous ones. In the multinomial logistic regression models we estimate a set of coefficients corresponding to each outcome category, i.e. to each type of living conditions in our case. (One of the categories is considered as reference, in our case this was the type neither with high cultural nor with high material assets.) The exponential value of coefficients is the relative risk ratio for one unit change in the corresponding variable. We present these values in our tables. For all procedures analytical weighting method was used. For estimations we used STATA 4.0. intercooled version. 
Table 2a. Social determination of living conditions, cultural assets only:

(Multinomial logit odds. Reference category is neither high cultural activities nor high material assets. Standard errors in parentheses)

\begin{tabular}{|c|c|c|c|c|c|c|}
\hline & Bulgaria & Czech Rep. & Hungary & Poland & Russia & Slovakia \\
\hline \multirow[t]{2}{*}{ income (deciles) } & 1.040 & 1.028 & $1.067 * * *$ & 1.033 & 1.010 & 0.991 \\
\hline & $(0.021)$ & $(0.015)$ & $(0.019)$ & $(0.023)$ & $(0.017)$ & $(0.016)$ \\
\hline \multirow[t]{2}{*}{ education (years) } & $1.476^{* * *}$ & $1.343 * * *$ & $1.388 * * *$ & $1.450 * * *$ & $1.264 * * *$ & $1.283 * * *$ \\
\hline & $(0.036)$ & $(0.027)$ & $(0.031)$ & $(0.040)$ & $(0.024)$ & $(0.027)$ \\
\hline \multirow[t]{2}{*}{ in labour force } & 1.019 & $1.248 *$ & $1.302 *$ & 1.078 & $1.425 * *$ & $1.433 * * *$ \\
\hline & $(0.125)$ & $(0.124)$ & $(0.138)$ & $(0.140)$ & $(0.181)$ & $(0.150)$ \\
\hline \multirow[t]{2}{*}{ higher controller } & 1.751 & $1.907 * * *$ & 1.773 & $2.175 * *$ & $1.948 * * *$ & $2.125 * * *$ \\
\hline & $(0.577)$ & $(0.379)$ & $(0.523)$ & $(0.618)$ & $(0.324)$ & $(0.456)$ \\
\hline \multirow[t]{2}{*}{ lower controller } & $1.879 * * *$ & $2.295 * * *$ & $2.416 * * *$ & $3.448 * * *$ & $2.488 * * *$ & $3.802 * * *$ \\
\hline & $(0.338)$ & $(0.309)$ & $(0.431)$ & $(0.768)$ & $(0.347)$ & $(0.613)$ \\
\hline \multirow[t]{2}{*}{ routine non-manual } & $1.493^{*}$ & $1.762 * * *$ & $1.797 * * *$ & $1.659 * *$ & $1.613 * * *$ & $1.601 * * *$ \\
\hline & $(0.284)$ & $(0.214)$ & $(0.264)$ & $(0.271)$ & $(0.236)$ & $(0.209)$ \\
\hline self-employed & 3.353 & 1.890 & 1.869 & 1.114 & 0.820 & 0.986 \\
\hline with employees & $(2.700)$ & $(1.103)$ & $(1.505)$ & $(0.697)$ & $(0.922)$ & $(1.108)$ \\
\hline self-employed & 1.696 & 0.610 & 0.876 & 1.727 & 1.027 & 1.113 \\
\hline without employees & $(0.549)$ & $(0.176)$ & $(0.243)$ & $(0.546)$ & $(0.470)$ & $(0.322)$ \\
\hline \multirow[t]{2}{*}{ self-employed farmer } & 0.179 & 0.993 & 0.514 & $0.392 * *$ & 0.337 & 0.636 \\
\hline & $(0.161)$ & $(0.691)$ & $(0.282)$ & $(0.119)$ & $(0.324)$ & $(0.417)$ \\
\hline \multirow[t]{2}{*}{ second farm in 1992} & 1.591 & 0.688 & 1.026 & 0.852 & 1.251 & $0.758)$ \\
\hline & $(0.521)$ & $(0.697)$ & $(0.229)$ & $(0.286)$ & $(0.205)$ & $(0.343)$ \\
\hline \multirow[t]{2}{*}{ second business in 1992} & 2.917 & 1.207 & 1.575 & 1.061 & 2.051 & 1.869 \\
\hline & $(2.147)$ & $(0.673)$ & $(0.638)$ & $(0.492)$ & $(0.845)$ & $(0.916)$ \\
\hline \multirow[t]{2}{*}{ second job in 1992} & 1.912 & $0.412 *$ & 1.535 & 1.321 & $2.608 * * *$ & 0.483 \\
\hline & $(1.695)$ & $(0.178)$ & $(0.464)$ & $(0.386)$ & $(0.581)$ & $(0.272)$ \\
\hline \multirow[t]{2}{*}{$\operatorname{sex}$} & 0.805 & $0.496 * * *$ & $0.586 * * *$ & $0.678 * *$ & 0.984 & $0.665 * * *$ \\
\hline & $(0.091)$ & $(0.044)$ & $(0.062)$ & $(0.086)$ & $(0.100)$ & $(0.065)$ \\
\hline \multirow[t]{2}{*}{ age } & $0.990^{*}$ & $1.030 * * *$ & 1.005 & 1.004 & $0.984 * * *$ & $1.017 * * *$ \\
\hline & $(0.004)$ & $(0.003)$ & $(0.004)$ & $(0.005)$ & $(0.003)$ & $(0.003)$ \\
\hline \multirow[t]{2}{*}{ town } & $1.318^{*}$ & $1.212 *$ & $1.970 * * *$ & $1.377^{*}$ & 0.929 & 1.093 \\
\hline & $(0.178)$ & $(0.106)$ & $(0.237)$ & $(0.206)$ & $(0.129)$ & $(0.105)$ \\
\hline \multirow[t]{2}{*}{ city } & $2.767 * * *$ & $2.100 * * *$ & $2.095 * * *$ & $2.280 * * *$ & $1.302 *$ & $1.970 * *$ \\
\hline & $(0.429)$ & $(0.297)$ & $(0.342)$ & $(0.357)$ & $(0.160)$ & $(0.430)$ \\
\hline \multirow[t]{2}{*}{ capital } & $2.165 * * *$ & $2.220 * * *$ & $3.103 * * *$ & $2.304 * *$ & $1.510^{*}$ & $1.754 * *$ \\
\hline & $(0.500)$ & $(0.331)$ & $(0.509)$ & $(0.712)$ & $(0.297)$ & $(0.318)$ \\
\hline \multirow[t]{2}{*}{ second farm in 1988} & $0.418 * *$ & 1.132 & 0.930 & 0.867 & 0.953 & 1.013 \\
\hline & $(0.140)$ & $(1.190)$ & $(0.204)$ & $(0.285)$ & $(0.159)$ & $(0.463)$ \\
\hline \multirow[t]{2}{*}{ second business in 1988} & 9.496 & 0.944 & 1.161 & 1.981 & $0.207^{*}$ & 1.162 \\
\hline & $(0.363)$ & $(0.665)$ & $(0.525)$ & $(1.563)$ & $(0.141)$ & $(0.918)$ \\
\hline \multirow[t]{2}{*}{ second job in 1988} & 1.317 & $3.313 *$ & 1.390 & 1.002 & 0.721 & 1.783 \\
\hline & $(1.429)$ & $(1.863)$ & $(0.372)$ & $(0.354)$ & $(0.197)$ & $(1.051)$ \\
\hline \multirow[t]{2}{*}{ communist party member } & $1.581 *$ & 1.204 & 1.374 & 1.685 & 1.293 & $1.401 *$ \\
\hline & $(0.320)$ & $(0.154)$ & $(0.291)$ & $(0.478)$ & $(0.233)$ & $(0.210)$ \\
\hline
\end{tabular}


Table 2a. (continued)

\begin{tabular}{|c|c|c|c|c|c|c|}
\hline & Bulgaria & Czech $R_{1}$ & Hungary & Poland & Russia & Slovakia \\
\hline $\log \mathrm{Li}$ & -3194.386 & -6050.098 & -4382.053 & -3241.669 & -4470.770 & -4773.133 \\
\hline Number of obs & 3255 & 5049 & 4319 & 3081 & 3765 & 4098 \\
\hline$\chi^{2}(63)$ & 1765.71 & 1533.39 & 2377.10 & 1706.13 & 1194.43 & 1354.44 \\
\hline Prob $>\chi^{2}$ & 0.0000 & 0.0000 & 0.0000 & 0.0000 & 0.0000 & 0.0000 \\
\hline Pseudo $\mathrm{R}^{2}$ & 0.2165 & 0.1125 & 0.2134 & 0.2083 & 0.1178 & 0.1243 \\
\hline
\end{tabular}

The reference category for occupation is manual workers, for place of residence it is village. Level of significance: $* * *=.0001, * *=.001, *=.05$

Higher education improves the likelihood of better living conditions significantly. To be precise, education is a more important factor for high cultural activities and it is less important for living under good material conditions, for which income is more important. As regards income, the odds of higher education are the highest for those living conditions of the 'consistent uppers' who are above the country average in respect of both cultural activities and material assets. The odds for education are somewhat higher in Hungary, Poland and Bulgaria as compared to Czech Republic, Slovakia and Russia.

Labour force participation does not play an important role in its effect on living conditions - if controlled for the other explanatory variables. It does not count in Bulgaria at all, and has moderate influence in the other countries.

The inconsistent - cultural vs. material - lifestyles are determined in characteristically different ways by class. High culture participation is influenced by white-collar occupations (high and low controllers and routine non-manuals), while material assets are affected by market-oriented occupations (the self employed with or without employees). However, the likelihood of belonging to the 'consistent upper' type of both high material and cultural assets is improved by both service and market-oriented occupations including both controllers and self-employed. However, being a self-employed farmer does not mean an advantageous position for any type of lifestyle in the examined countries. In fact, this class category influences high culture participation negatively in Poland and Bulgaria.

These results seem to be in line with Bourdieu's concept on cultural and material lifestyle. The relative risk of high cultural activities without material assets contrasted to the category of neither high material assets nor high culture participation is 2-4 times larger for low controllers and routine non-manuals compared to manual workers and farm labourers. At the same time, market-oriented occupations do not significantly improve the likelihood of high cultural activities. On the other hand, non-agricultural self-employed respondents have a 2-9 times higher likelihood of belonging to the type of material lifestyle without cultural activities. For the 'consistent uppers' type of living conditions with both cultural and material assets, either 'intellectual' or 'market oriented' class positions improve the odds strongly. 
Table 2b. Social determination of living conditions, material assets only:

(Multinomial logit odds. Reference category is neither high cultural activities nor high material assets. Standard errors in parentheses)

\begin{tabular}{|c|c|c|c|c|c|c|}
\hline & Bulgaria & Czech Rep. & Hungary & Poland & Russia & Slovakia \\
\hline \multirow[t]{2}{*}{ income (deciles) } & $1.110 * * *$ & * $1.130 * * *$ & $1.169 * * *$ & $1.194 * * *$ & $1.064 * * *$ & $1.114 * * *$ \\
\hline & $(0.024)$ & $(0.018)$ & $(0.022)$ & $(0.025)$ & $(0.019)$ & $(0.020)$ \\
\hline \multirow[t]{2}{*}{ education (years) } & $1.159 * * *$ & $1.103 * * *$ & $1.186^{* * *}$ & $1.132 * * *$ & $1.073 * * *$ & $1.195 * * *$ \\
\hline & $(0.031)$ & $(0.025)$ & $(0.028)$ & $(0.032)$ & $(0.021)$ & $(0.029)$ \\
\hline \multirow[t]{2}{*}{ in labour force } & 0.971 & $1.405^{* *}$ & $1.654 * * *$ & $1.341^{*}$ & 0.973 & $1.435^{* *}$ \\
\hline & $(0.129)$ & $(0.154)$ & $(0.187)$ & $(0.180)$ & $(0.121)$ & $(0.177)$ \\
\hline \multirow[t]{2}{*}{ higher controller } & 1.288 & $1.874 * *$ & 1.380 & 1.108 & 1.152 & $1.631^{*}$ \\
\hline & $(0.534)$ & $(0.418)$ & $(0.475)$ & $(0.380)$ & $(0.222)$ & $(0.401)$ \\
\hline \multirow[t]{2}{*}{ lower controller } & $1.644^{*}$ & $1.566 * *$ & 1.288 & $2.029 * *$ & 1.172 & $2.021 * * *$ \\
\hline & $(0.358)$ & $(0.245)$ & $(0.282)$ & $(0.498)$ & $(0.194)$ & $(0.394)$ \\
\hline \multirow[t]{2}{*}{ routine non-manual } & 1.520 & $1.430 *$ & $1.699 * * *$ & 1.337 & 0.932 & 1.253 \\
\hline & $(0.351)$ & $(0.204)$ & $(0.275)$ & $(0.231)$ & $(0.155)$ & $(0.199)$ \\
\hline self-employed & 1.060 & $4.667 * *$ & $5.663 * *$ & $5.621 * * *$ & $8.735 * *$ & $7.241 * *$ \\
\hline with employees & $(1.303)$ & $(2.386)$ & $(3.813)$ & $(2.730)$ & $(7.110)$ & $(5.601)$ \\
\hline self-employed & $2.050^{*}$ & $1.789 * *$ & $2.085 * * *$ & $3.643 * * *$ & 1.532 & 0.978 \\
\hline without employees & $(0.703)$ & $(0.387)$ & $(0.458)$ & $(0.972)$ & $(0.689)$ & $(0.314)$ \\
\hline \multirow[t]{2}{*}{ self-employed farmer } & 0.611 & 2.529 & 1.787 & 0.854 & 1.614 & 0.868 \\
\hline & $(0.285)$ & $(1.453)$ & $(0.608)$ & $(0.169)$ & $(0.815)$ & $(0.517)$ \\
\hline \multirow[t]{2}{*}{ second farm in 1992} & 1.628 & $1.1 \mathrm{e}-9 * * *$ & * $\quad 0.983$ & 1.571 & 1.110 & 1.248 \\
\hline & $(0.547)$ & $(1.4 \mathrm{e}-9)$ & $(0.212)$ & $(0.462)$ & $(0.212)$ & $(0.624)$ \\
\hline \multirow[t]{2}{*}{ second business in 1992} & 2.198 & 2.122 & 1.988 & 1.137 & 1.498 & 0.895 \\
\hline & $(1.808)$ & $(1.156)$ & $(0.760)$ & $(0.497)$ & $(0.658)$ & $(0.551)$ \\
\hline \multirow[t]{2}{*}{ second job in 1992} & 0.358 & 0.423 & 1.662 & 0.773 & 1.395 & 0.262 \\
\hline & $(0.521)$ & $(0.218)$ & $(0.550)$ & $(0.261)$ & $(0.378)$ & $(0.212)$ \\
\hline \multirow[t]{2}{*}{$\operatorname{sex}$} & $1.353 *$ & 0.902 & 0.832 & 0.801 & 1.112 & 1.006 \\
\hline & $(0.168)$ & $(0.085)$ & $(0.092)$ & $(0.098)$ & $(0.117)$ & $(0.112)$ \\
\hline \multirow[t]{2}{*}{ age } & 0.995 & 0.998 & 0.999 & 0.991 & $1.016 * * *$ & 1.002 \\
\hline & $(0.005)$ & $(0.003)$ & $(0.004)$ & $(0.005)$ & $(0.003)$ & $(0.004)$ \\
\hline \multirow[t]{2}{*}{ town } & $1.331 *$ & 0.927 & 1.197 & $1.473 * *$ & 1.175 & $0.676^{* * *}$ \\
\hline & $(0.191)$ & $(0.086)$ & $(0.141)$ & $(0.209)$ & $(0.150)$ & $(0.074)$ \\
\hline \multirow[t]{2}{*}{ city } & $1.458^{*}$ & 0.994 & 1.071 & $1.478^{*}$ & $0.693 * *$ & $0.388 * *$ \\
\hline & $(0.275)$ & $(0.169)$ & $(0.192)$ & $(0.237)$ & $(0.087)$ & $(0.138)$ \\
\hline \multirow[t]{2}{*}{ capital } & $3.243 * * *$ & 1.115 & $2.292 * * *$ & 1.430 & $0.544 *$ & 0.885 \\
\hline & $(0.785)$ & $(0.195)$ & $(0.385)$ & $(0.486)$ & $(0.141)$ & $(0.195)$ \\
\hline \multirow[t]{2}{*}{ second farm in 1988} & 0.843 & $1.3 \mathrm{e} 9 * * *$ & 1.164 & 0.794 & 1.366 & 0.670 \\
\hline & $(0.285)$ & $(1.6 \mathrm{e} 9)$ & $(0.246)$ & $(0.231)$ & $(0.261)$ & $(0.342)$ \\
\hline \multirow[t]{2}{*}{ second business in 1988} & 0.627 & 0.479 & $3.466 * * *$ & 1.897 & 0.834 & 1.540 \\
\hline & $(0.500)$ & $(0.368)$ & $(1.352)$ & $(1.436)$ & $(0.499)$ & $(1.331)$ \\
\hline \multirow[t]{2}{*}{ second job in 1988} & 1.027 & 2.825 & 0.818 & 0.976 & 0.970 & 1.752 \\
\hline & $(1.624)$ & $(1.786)$ & $(0.263)$ & $(0.378)$ & $(0.290)$ & $(1.230)$ \\
\hline \multirow[t]{2}{*}{ communist party member } & $1.680 *$ & 1.083 & 1.250 & 1.209 & 1.276 & $1.637 * *$ \\
\hline & $(0.378)$ & $(0.156)$ & $(0.295)$ & $(0.377)$ & $(0.239)$ & $\begin{array}{c}(0.265) \\
\text { (continued) }\end{array}$ \\
\hline
\end{tabular}


Table 2b. (continued)

\begin{tabular}{lcccccc} 
& Bulgaria & Czech Rep. & Hungary & Poland & \multicolumn{1}{c}{ Russia } & Slovakia \\
\hline Log Likelihood & -3194.386 & -6050.098 & -4382.053 & -3241.669 & -4470.770 & -4773.133 \\
Number of obs & 3255 & 5049 & 4319 & 3081 & 3765 & 4098 \\
$\chi^{2}(63)$ & 1765.71 & 1533.39 & 2377.10 & 1706.13 & 1194.43 & 1354.44 \\
Prob $>\chi^{2}$ & 0.0000 & 0.0000 & 0.0000 & 0.0000 & 0.0000 & 0.0000 \\
Pseudo $R^{2}$ & 0.2165 & 0.1125 & 0.2134 & 0.2083 & 0.1178 & 0.1243 \\
\hline
\end{tabular}

The reference category for occupation is manual workers, forplace of residence it is village. Level of significance: $* * *=.0001, * *=.001, *=.05$

Class determination seems to have high country specific variation. For example, a low controller position matters much more in Poland and Slovakia. Non-agricultural selfemployed respondents are much more likely to live under high material conditions in Russia, Slovakia, Hungary and Poland compared to Bulgaria and Czech Republic. The largest country variation is shown for the 'consistent uppers' type with both cultural and material assets. Especially new large-scale entrepreneurs with employees in the less developed post-communist societies have much more of a chance of belonging to this category. (E.g. large-scale Russian entrepreneurs are a 12 times larger likelier to have both cultural and material assets when contrasted to manual workers and the category of neither high material nor high cultural assets.)

The impact of participation in the informal economy on living conditions is low if it is controlled for the other explanatory variables including also informal economy activities in 1988. A second job in Russia means a higher chance of an inconsistent cultural lifestyle, whilst a second business activity in Hungary results in significantly higher odds for the 'consistent uppers' type, even in this case. In Hungary this can be a consequence of old traditions of informal economy participation dating back to the seventies which has undoubtedly survived the system change. In Russia, however, the formal market relations may be less developed and this fact increases the significance of the informal economy.

For the demographic set of variables, some gender effects were found indicating that women 'consume more culture' than men. Age effects are very small, they do not exist for Hungary and Poland at all. Some country variation appears: an older age is more advantageous for better living conditions in Czech Republic and Slovakia, while youngsters 'consume more culture' in Bulgaria and Russia.

Regional differences seem to influence living conditions to a higher degree. From villages to the capitals, from less-urbanised to more-urbanised settlements, the odds of high culture consumption increase in almost all of the post-communist societies. This impact is the strongest for Hungary where the results indicate a 3 times higher chance of high culture participation without material assets in Budapest, whereas it is less present for Russia and Slovakia. 
Table 2c. Social determination of living conditions, both cultural and material assets:

(Multinomial logit odds. Reference category is neither high cultural activities nor high material assets. Standard errors in parentheses)

\begin{tabular}{|c|c|c|c|c|c|c|}
\hline & Bulgaria $\mathrm{C}_{2}$ & Czech Rep. & Hungary & Poland & Russia & Slovakia \\
\hline \multirow[t]{2}{*}{ income (deciles) } & $1.185^{* * *}$ & $* \quad 1.171 * * *$ & $1.221 * * *$ & $1.280 * * *$ & $1.133 * * *$ & $1.152 * * *$ \\
\hline & $(0.027)$ & $(0.020)$ & $(0.023)$ & $(0.030)$ & $(0.021)$ & $(0.020)$ \\
\hline \multirow[t]{2}{*}{ education (years) } & $1.527 * * *$ & $1.412 * * *$ & $1.543 * * *$ & $1.511 * * *$ & $1.279 * * *$ & $1.339 * * *$ \\
\hline & $(0.041)$ & $(0.031)$ & $(0.036)$ & $(0.043)$ & $(0.026)$ & $(0.030)$ \\
\hline \multirow[t]{2}{*}{ in labour force } & 1.325 & $1.252 *$ & $1.847 * * *$ & 0.902 & 1.258 & $1.628 * * *$ \\
\hline & $(0.191)$ & $(0.141)$ & $(0.209)$ & $(0.125)$ & $(0.184)$ & $(0.196)$ \\
\hline \multirow[t]{2}{*}{ higher controller } & $2.433 * *$ & $2.279 * * *$ & $4.360 * * *$ & $3.478 * * *$ & $3.566 * * *$ & $3.838 * * *$ \\
\hline & $(0.810)$ & $(0.470)$ & $(1.210)$ & $(0.982)$ & $(0.610)$ & $(0.817)$ \\
\hline \multirow[t]{2}{*}{ lower controller } & $2.630 * * *$ & $3.016^{* * *}$ & $2.914 * * *$ & $4.914 * * *$ & $2.813 * * *$ & $5.439 * * *$ \\
\hline & $(0.504)$ & $(0.431)$ & $(0.531)$ & $(1.131)$ & $(0.438)$ & $(0.914)$ \\
\hline \multirow[t]{2}{*}{ routine non-manual } & $2.593 * * *$ & $2.158 * * *$ & $2.254 * * *$ & $2.240 * * *$ & 1.213 & $2.118 * * *$ \\
\hline & $(0.521)$ & $(0.292)$ & $(0.350)$ & $(0.398)$ & $(0.223)$ & $(0.305)$ \\
\hline self-employed & $5.728 *$ & $3.667 *$ & $9.082 * * *$ & $8.469 * * *$ & $12.743 * * *$ & $8.275^{* *}$ \\
\hline with employees & $(4.561)$ & $(2.040)$ & $(5.911)$ & $(4.080)$ & $(10.060)$ & $(6.387)$ \\
\hline self-employed & $2.199 *$ & 1.206 & $2.416^{* * *}$ & $4.692 * * *$ & 1.505 & $1.805^{*}$ \\
\hline without employees & $(0.766)$ & $(0.312)$ & $(0.543)$ & $(1.336)$ & $(0.699)$ & $(0.504)$ \\
\hline \multirow[t]{2}{*}{ self-employed farmer } & $5 \mathrm{e}-16^{* * *}$ & 2.851 & 0.726 & 1.327 & 0.468 & 2.215 \\
\hline & $(1 \mathrm{e}-8)$ & $(1.705)$ & $(0.375)$ & $(0.363)$ & $(0.471)$ & $(1.085)$ \\
\hline \multirow[t]{2}{*}{ second farm in 1992} & 1.237 & $1 \mathrm{e}-10 * * *$ & 1.209 & 1.389 & 1.400 & 0.727 \\
\hline & $(0.484)$ & $(0.000)$ & $(0.291)$ & $(0.472)$ & $(0.259)$ & $(0.346)$ \\
\hline \multirow[t]{2}{*}{ second business in 1992} & 3.350 & 2.590 & $3.021 * *$ & 0.933 & 2.083 & 1.689 \\
\hline & $(2.436)$ & $(1.366)$ & $(1.085)$ & $(0.409)$ & $(0.877)$ & $(0.850)$ \\
\hline \multirow[t]{2}{*}{ second job in 1992} & 2.216 & 0.605 & 1.366 & 1.073 & 1.241 & 0.892 \\
\hline & $(1.974)$ & $(0.256)$ & $(0.415)$ & $(0.319)$ & $(0.325)$ & $(0.464)$ \\
\hline \multirow[t]{2}{*}{$\operatorname{sex}$} & 0.991 & $0.530 * * *$ & $0.704 * *$ & 0.786 & 0.892 & $0.668 * * *$ \\
\hline & $(0.127)$ & $(0.052)$ & $(0.079)$ & $(0.105)$ & $(0.103)$ & $(0.072)$ \\
\hline \multirow[t]{2}{*}{ age } & 0.990 & $1.021 * * *$ & 0.997 & 0.998 & $0.988 * *$ & $1.013 * *$ \\
\hline & $(0.005)$ & $(0.003)$ & $(0.004)$ & $(0.005)$ & $(0.004)$ & $(0.004)$ \\
\hline \multirow[t]{2}{*}{ town } & $1.965 * * *$ & 1.173 & $1.868 * * *$ & $2.835 * * *$ & 0.889 & 1.122 \\
\hline & $(0.325)$ & $(0.118)$ & $(0.239)$ & $(0.471)$ & $(0.141)$ & $(0.118)$ \\
\hline \multirow[t]{2}{*}{ city } & $3.849 * * *$ & $1.573 * *$ & $1.963 * * *$ & $4.110 * * *$ & 1.222 & 1.389 \\
\hline & $(0.713)$ & $(0.255)$ & $(0.338)$ & $(0.721)$ & $(0.169)$ & $(0.336)$ \\
\hline \multirow[t]{2}{*}{ capital } & $6.585 * * *$ & $2.331 * * *$ & $5.078 * * *$ & $3.956 * * *$ & $1.638^{*}$ & $1.939 * * *$ \\
\hline & $(1.568)$ & $(0.371)$ & $(0.836)$ & $(1.250)$ & $(0.360)$ & $(0.366)$ \\
\hline \multirow[t]{2}{*}{ second farm in 1988} & 0.623 & $7 \mathrm{e}+9 * * *$ & 0.734 & 0.758 & 1.177 & 1.281 \\
\hline & $(0.246)$ & $(2 \mathrm{e}+9)$ & $(0.176)$ & $(0.256)$ & $(0.220)$ & $(0.613)$ \\
\hline \multirow[t]{2}{*}{ second business in 1988} & 0.727 & 0.256 & 2.151 & 3.615 & 0.497 & 1.679 \\
\hline & $(0.518)$ & $(0.203)$ & $(0.847)$ & $(2.682)$ & $(0.292)$ & $(1.253)$ \\
\hline \multirow[t]{2}{*}{ second job in 1988} & 0.790 & 2.889 & 1.379 & 1.226 & 1.362 & 1.509 \\
\hline & $(0.903)$ & $(1.673)$ & $(0.373)$ & $(0.428)$ & $(0.397)$ & $(0.882)$ \\
\hline \multirow[t]{2}{*}{ communist party member } & $1.872 * *$ & 1.165 & 1.273 & 1.634 & $1.738^{* *}$ & $1.754 * * *$ \\
\hline & $(0.391)$ & $(0.163)$ & $(0.275)$ & $(0.476)$ & $(0.318)$ & $(0.265)$ \\
\hline
\end{tabular}


Péter Róbert: Social Determination of Living Conditions in Post-Communist Societies

Table 2c. (continued)

\begin{tabular}{lcccccc} 
& Bulgaria & Czech Rep. & Hungary & Poland & Russia & Slovakia \\
\hline Log Likelihood & -3194.386 & -6050.098 & -4382.053 & -3241.669 & -4470.770 & -4773.133 \\
Number of obs & 3255 & 5049 & 4319 & 3081 & 3765 & 4098 \\
$\chi^{2}(63)$ & 1765.71 & 1533.39 & 2377.10 & 1706.13 & 1194.43 & 1354.44 \\
Prob $>\chi^{2}$ & 0.0000 & 0.0000 & 0.0000 & 0.0000 & 0.0000 & 0.0000 \\
Pseudo R & 0.2165 & 0.1125 & 0.2134 & 0.2083 & 0.1178 & 0.1243 \\
\hline
\end{tabular}

The reference category for occupation is manual workers, for place of residence it is village.

Level of significance: $* * *=.0001, * *=.001, *=.05$

For the inconsistent type of material assets without high culture consumption the data indicate a strong positive impact only for the Bulgarian and Hungarian capitals where the chances are 2-3 times higher of belonging to this category. There is no significant connection between place of residence and material lifestyle in Czech Republic. For Poland, residents of small towns and cities are a bit more likely to live under good material conditions and not participate in high culture than the inhabitants of Warsaw. For Russia and Slovakia the estimates show a greater likelihood of this category being found in villages, in contrast to towns and cities which are more characterised by the 'consistent lowers' type of living conditions. This result displays strong country variations showing that this type of inconsistency is more typical for respondents in Russian and Slovakian villages and for inhabitants of Sofia and Budapest.

For the 'consistent uppers' type of living conditions with both material and cultural assets, the 'residential ladder' seems to be the steepest. Regional inequality is especially strong in the two countries with a 'hydrocephalus' settlement hierarchy: Bulgaria and Hungary. Residents of Sofia or Budapest have 5-6 times more chance of belonging to this type relative to those living in villages and of being in the 'consistent lowers' type of living conditions. This holds for respondents from the Russian and Slovakian capitals much less, while the residents of Warsaw and Prague are in between.

Few estimates for participation in the informal economy in 1988 are significant if controlled for the other explanatory variables. For inconsistent cultural activities, this is farming in Bulgaria and second business in Russia - both have a negative impact. In the latter case the explanation can be that market activity was so close to doing something illegal in the former Soviet Union that only a very special group with low cultural status would risk doing it. In Czech Republic, respondents were producing agricultural products for the market as early as 1988 now live under much better material conditions. This holds for the type of both material and cultural assets as well. Lastly, in Hungary the 'early businessmen' who established their second business in the 1980s, have a 3 times better chance of belonging to the inconsistent material type of living conditions.

Previous Communist Party membership was also expected to affect present living conditions especially in the societies where the centralised party power was the strongest. In fact, when controlling for all other variables, we found significant influence of previous Party membership only for Bulgaria, Slovakia and Russia. These effects are somewhat stronger for the type of 'consistent uppers' with both cultural and material assets. 


\section{Discussion}

The goal of this paper was to present the socio-demographic determination of living conditions in six East European post-communist societies which are on the way from centralised, politically determined redistributive systems to market economies. In the analysis two theories were built on: the concept of economic and cultural lifestyle by Bourdieu [1984] and the status inconsistency theory by Lenski [1954], Machonin [1970], Kolosi [1984] and others. In the paper such terms as 'consistent lower' and 'consistent upper' living conditions are referred to, as well as inconsistent types dominated by 'pure' cultural or 'pure' material lifestyle. In the analysis I attempted to reveal the reasons why a person belongs to one or another type of living conditions. I also aimed to highlight country specific variations among the six societies.

From previous stratification research it is known that status inconsistency was high in the East European societies under socialism. As a consequence of the egalitarian ideology and practice of communist governments, one form of inconsistency was that income differences were relatively small compared to the existing occupational and educational inequalities. At the same time, while salaries were kept artificially low, consumer prices were also subsidised. Thus, consumption was less dependent on income as compared to Western societies and this also made it possible to maintain the illusion of equality. Lifestyle and cultural reproduction research highlighted the hidden and mostly culturally based mechanisms of inequalities only in the late eighties [Róbert 1984; Kolosi 1987; Mateju 1990; Ganzeboom, De Graaf and Róbert 1990].

The results still indicate a weak explanatory power of income three years after the economic and political turnabout. Although estimates for income are statistically significant, the relative risk ratios are very close to 1, especially for the type of cultural lifestyle but also for the other two types of living conditions. While high culture participation seems to be almost as inexpensive as it was under the previous regime, it is much more affected by high education, managerial, professional or non-manual class position and residential status. When characterising the group of individuals who belong to the inconsistent type of cultural lifestyle with lower material assets than the country average, we can speak about educated people in low controller or routine non-manual positions who are likely to be females and who live in more urbanised settlements.

The group of individuals who belong to the other inconsistent group with higher material assets but lower cultural participation than the country average, might be similar to the snobs of the French Revolution. They are the nouveau riches, although they are better educated than those who have neither cultural nor material assets. Good material living conditions can be attained by being active in the newly developed market and - in some cases - in the informal economy. Having a high income and - in some countries previous Communist Party membership are also among the requirements. Higher education also improves the likelihood of living under good material conditions but it is less important compared to the case of the other types of living conditions. When characterising this type of living conditions, market related activity, some kind of entrepreneurship and a good financial position, should be emphasised. It is not accidental that recent research in Hungary on participation in the hidden economy is approached by economists by means of investigating consumption [Árvay and Vértes 1995].

While results on class cleavages are quite close to Bourdieu's concept on social determination of economic and cultural lifestyle, I would like to underline a significant dif- 
ference as characteristic for the post-communist societies and this is the higher degree of status inconsistency. In the Western societies following an economic lifestyle does not mean having fewer cultural assets than the country average, and following a cultural lifestyle does not mean living under worse material conditions than the country average. However, this can be observed in the post-communist countries and this feature of these societies is in line with inconsistent middle class formation [Róbert and Sági 1994]. While inconsistency seems to survive the economic and political transformation, there is a consistent type of living conditions with high culture participation and good material assets in these societies. But in order to belong to this category people have to have in combination all forms of resources, such kinds of advantages as high income, good education, a powerful position in the labour market, controller job or entrepreneurship, participation in the informal economy, starting market activity as early as in the late eighties, and - in the most rigorously Soviet-type societies - having a good political 'past' and connections.

In respect of country variation the most typical approach divides the six countries investigated here into two groups: Czech Republic, Hungary, Poland on the one hand, and Bulgaria, Russia, Slovakia on the other. This is based on the assumption that the first group is closer to the Western type of societies than the second, partly due to differences in economic development and earlier introduced market characteristics, partly because of the earlier introduced democratic changes and weaker redistributive pressures of party power. Indeed, our analysis confirms this view to some degree. Especially when considering the influence of Communist Party membership, present living conditions are more strongly determined by the previous redistributive hierarchy in Bulgaria, Russia and Slovakia. However, when analysing the impact of participation in the informal economy, the two groups appear as Hungary, Bulgaria, Russia versus Czech Republic, Slovakia, Poland. Moreover the role of the informal economy has quite different roots in these societies: long-lasting traditions of informal economy activities in Hungary, and lessdeveloped market relations in Bulgaria and Russia. Finally, in respect of regional differences, the unequal spatial distribution of cultural institutional possibilities and of material living conditions indicate a division between Bulgaria and Hungary on the one hand and the other four countries on the other.

The division of the societies investigated seems to display another pattern again for the explanatory power of the models used in the analysis. We can conclude that the attempt to find the determinants of belonging to different types of living conditions was moderately successful. This model explains about $21 \%$ of the variance for Bulgaria, Hungary, Poland and only about $12 \%$ for Czech Republic, Russia, and Slovakia. There is a common feature of the causal relationship in these societies, namely that income has a significant but small effect on living conditions, while the other components of social status, education and class have much stronger influence. In fact, the variation between these societies was caused by the influence of class and education on living conditions which turned out to be stronger for Bulgaria, Hungary and Poland when compared to Czech Republic, Russia and Slovakia. This grouping brings together the two 'reformcommunist' countries (Hungary and Poland) and the two countries that used to be one (Czech Republic and Slovakia). The reason why Bulgaria and Russia fall into different groups and why they differ so much in this respect is somewhat unclear and needs further investigation. 


\section{Appendix}

For material consumption six dichotomous variables ( 0 vs. 1) were used showing whether the respondent's family has automatic washing machine, video cassette recorder, satellite receiver, microwave oven, deep freezer, personal computer, as well as two further continuous variables which were considered the living territory for a person in the household ( $\mathrm{M}^{2}$ per capita) and the total value of vehicles owned by the respondent's household (0 if none). (See also Table A1.)

Since the observed frequencies of these variables differ within countries and they are of country specific character, they were normalised separately for each of the countries. Accordingly, the so-called z-scores of these variables show the divergence of the respondents' material conditions from their own societies' average. The eight normalised variables were added together resulting in a continuous score for material living conditions. This method means that: (1) the more durables the respondent's family has the higher score the variable of material assets; (2) and also the less common and frequently widespread durables the respondent's family owns the higher score the variable of material assets.

For measuring cultural participation seven-grade variables were used on the respondents' activities in five fields of cultural consumption, i.e. how often the respondent goes to art museums or art exhibits, to ballet, opera, theatre or concerts, listens to classical music at home, reads 'serious' books such as history, biography, science or literature, goes to the library, as well as a nine-grade variable on the number of books a respondent has. (See also Table A2.)

Based on the same consideration, these variables were again normalised separately for each of the countries and then they were added together resulting in a score for cultural living conditions. This measurement has the same features as the previous one for material assets.

In the next step dichotomous variables were computed from the continuous scores for the material and cultural assets where the cutting point was if the respondent had a higher score than his/her country specific average (1) or not (0). The dependent variable of the analysis is derived from the combination of these two dichotomous variables distinguishing four types:

- if the respondent's position is not better than his/her country specific average is in respect of either cultural or material consumption;

- if the respondent's position is better in respect of cultural activities than his/her country specific average is, but this is not the case for material assets;

- if the respondent's position is better in respect of material assets than his/her country specific average is, but this is not the case for cultural activities; and

- if the respondent's position is better in respect of both cultural and material consumption than his/her country specific average is.

For income it was assumed that the consumption unit in modern societies is the family, therefore family income was used instead of personal income. Since we are speaking of respondents' cultural and material assets relative to their country specific averages, it was appropriate to use income deciles. The deciles were calculated separately for each of the examined countries.

The respondents' educational level was measured by years in school. For labour force participation we used a dummy variable with code 1 (in the labour force) and 0 (out of the labour force) at the time of interview. The occupation (present or most recent) is based on the EriksonGoldthorpe-Portocarero class classification: high controllers; low controllers; routine nonmanuals; self employed with employees; self-employed without employees; self-employed farmers; manual supervisors; skilled workers; semi- and unskilled workers; agricultural labourers [Erikson and Goldthorpe 1992]. For the multivariate models dummy variables were computed distinguishing between high controllers, low controllers, routine non-manuals, and the three self employed categories, while the manual worker categories were considered as reference.

For demographic position gender $(0=$ female; $1=$ male $)$ was included, age at the time of data collection (in 1993); and size of residence (village, town, city and capital of the country). For the 
multivariate models dummy variables were computed for each category of residential position and village was used as reference.

For measuring participation in the informal economy there were a series of dummy variables such as part-time activity in agriculture $(0=$ not, $1=$ yes $)$; part-time activity in non-agricultural business $(0=$ not, $1=$ yes $)$; other part-time activities or second job $(0=$ not, $1=$ yes $)$. These measurements were computed for the time of survey as well as for 1988.

For measuring political participation before 1989 a dichotomous variable was applied: the respondent was a member of Communist Party in 1988 (1) or not (0).

Table A1. The proportion of certain consumer durables by countries (\%)

\begin{tabular}{lcccccr} 
& $\begin{array}{c}\text { Bulgaria } \\
(\mathrm{N}=3326)\end{array}$ & $\begin{array}{c}\text { Czech Rep. } \\
(\mathrm{N}=5040)\end{array}$ & $\begin{array}{c}\text { Hungary } \\
(\mathrm{N}=3808)\end{array}$ & $\begin{array}{c}\text { Poland } \\
(\mathrm{N}=3079)\end{array}$ & $\begin{array}{r}\text { Russia } \\
(\mathrm{N}=3616)\end{array}$ & $\begin{array}{r}\text { Slovakia } \\
(\mathrm{N}=4066)\end{array}$ \\
\hline \multicolumn{2}{l}{ automatic washing } & & & & & \\
machine & 32.7 & 65.6 & 41.5 & 59.3 & 89.9 & 52.3 \\
VCR & 23.7 & 24.0 & 37.5 & 53.7 & 8.9 & 22.5 \\
satellite & 1.7 & 8.8 & 20.6 & 11.4 & 0.5 & 13.3 \\
microwave & 2.2 & 8.1 & 14.8 & 5.1 & 2.2 & 7.5 \\
freezer & 5.4 & 68.6 & 64.4 & 44.4 & 10.0 & 63.5 \\
PC & 1.4 & 5.8 & 8.6 & 13.2 & 2.3 & 6.4 \\
car & 31.5 & 54.0 & 43.8 & 45.3 & 22.2 & 43.6 \\
\hline
\end{tabular}

Source: Stratification in Eastern Europe after 1989 survey

Table A2. Average frequencies for cultural consumption (standard deviations in brackets) by countries (measured on $0-6$ scale where $0=$ never, $6=$ more than once a week; for books $0=$ none, $8=$ more than 1000)

\begin{tabular}{lcccccc} 
& $\begin{array}{c}\text { Bulgaria } \\
(\mathrm{N}=3326)\end{array}$ & $\begin{array}{c}\text { Czech Rep. } \\
(\mathrm{N}=5040)\end{array}$ & $\begin{array}{c}\text { Hungary } \\
(\mathrm{N}=3808)\end{array}$ & $\begin{array}{c}\text { Poland } \\
(\mathrm{N}=3079)\end{array}$ & $\begin{array}{c}\text { Russia } \\
(\mathrm{N}=3616)\end{array}$ & $\begin{array}{r}\text { Slovakia } \\
(\mathrm{N}=4066)\end{array}$ \\
\hline museum & 0.80 & 1.05 & 1.04 & 0.85 & 0.84 & 1.14 \\
theatre & $(1.14)$ & $(1.23)$ & $(1.32)$ & $(1.15)$ & $(1.14)$ & $(1.24)$ \\
& 0.98 & 1.11 & 0.92 & 0.74 & 0.85 & 1.05 \\
classic music & $(1.30)$ & $(1.30)$ & $(1.29)$ & $(1.14)$ & $(1.18)$ & $(1.28)$ \\
book reading & 0.86 & 1.66 & 1.40 & 1.45 & 1.10 & 1.90 \\
library & $(1.65)$ & $(1.91)$ & $(1.94)$ & $(2.07)$ & $(1.77)$ & $(2.06)$ \\
& $(2.21$ & 3.30 & 2.09 & 2.12 & 3.30 & 3.13 \\
books & 0.78 & $(1.93)$ & $(2.10)$ & $(2.21)$ & $(2.18)$ & $(1.99)$ \\
& $(1.54)$ & $(1.73)$ & $(1.48)$ & $(1.48)$ & $(1.93)$ & $(1.70)$ \\
& 3.93 & 5.24 & 5.14 & 4.21 & 5.18 & 4.86 \\
& $(2.47)$ & $(1.60)$ & $(1.99)$ & $(2.02)$ & $(1.96)$ & $(1.70)$ \\
\hline
\end{tabular}

Source: Stratification in Eastern Europe after 1989 survey

PÉTER RÓBERT is Associate Professor at the Institute of Sociology, ELTE University, Budapest, and Head of Research Department in Social Research Informatics Center (TARKI), Budapest. His main interests are social stratification and mobility, labour market processes, attitudes towards social inequalities, political preferences. His contributions have been published in European Sociological Review and Research in Stratification and Mobility. 


\section{References}

Adamczuk, Lucjan, Rudolf Andorka, István Harcsa and Iris Niemi 1988. "Modernization and Time Budget in Finland, Hungary and Poland." Pp. 223-256 in In Memoriam Alexander Szalai. Hungarian Sociological Studies 2, ed. by L. Cseh-Szombathy. Budapest: Hungarian Sociological Association.

Árvay, János, András Vértes 1995. The Share of the Private Sector and the Hidden Economy in Hungary. Budapest: GKI Economic Research Company.

Bourdieu, Pierre 1973. "Cultural reproduction and social reproduction.” In Knowledge, Education and Cultural Change, ed. by R. Brown. London: Tavistock Publications.

Bourdieu, Pierre 1984. Distinction. A Social Critique of the Judgement of Taste. London: Routledge and Kegan Paul.

Bourdieu, Pierre, Jean-Claude Passeron 1977. Reproduction in Education, Society and Culture. London: Sage Publications.

Böröcz, József, Caleb Southworth 1996. "Decomposing the Intellectuals Class Power: Conversion of Cultural Capital to Income, Hungary, 1986.” Social Forces 74: 797-821.

Collins, Randall 1979. The Credential Society. New York: Academic Press.

De Graaf, Paul M. 1986. "The Impact of Financial and Cultural Resources on Educational Attainment in the Netherlands." Sociology of Education 59: 237-246.

De Graaf, Nan Dirk 1991. "Distinctions by Consumption in Czechoslovakia, Hungary and the Netherlands." European Sociological Review 7: 267-290.

DiMaggio, Paul 1982. "Cultural Capital and School Success: The Impact of Status Cultural Participation on the Grades of U.S. High School Students." American Sociological Review 47: 189-201.

DiMaggio, Paul, John Mohr 1985. "Cultural Capital, Educational Attainment and Marital Status." American Journal of Sociology 90: 1231-1257.

Erikson, Robert, John H. Goldthorpe 1992. The Constant Flux. Oxford: Clarendon Press.

Falussy, Béla, Viktor Zoltánka 1994. A magyar társadalom életmódjának változásai az 1976-77, az 1986-87 és az 1993. évi életmód-idõmérleg felvételek alapján (Changes in way of life in the Hungarian society based on way of life-time budget surveys from 1976-77, 1986-87 and 1993). Budapest: Central Statistical Office.

Filipcová, B. (ed.) 1972. "Society and Leisure. Special Issue on Socialist Life Style." Society and Leisure Time 4, no. 3.

Ganzeboom, Harry B. G., Paul M. De Graaf, Péter Róbert 1990. "Reproduction Theory on Socialist Ground: Intergenerational Transmission of Inequalities in Hungary." In Research in Social Stratification and Social Mobility 9, ed. by A. L. Kalleberg. Greenwich: JAI Press.

Gheliuta, A. M., S. P. Gogoliukhin 1974. “The formation of a new type of worker.” Pp. 169-203 in Transformations of Social Structure in USSR and Poland, ed. by M. N. Rutkevitch, W. Wesolowski, V. S Semyonov, M. Jarosinska, V. V. Kolbanovsky. Moscow-Warsaw: Institute of Sociological Research. Academy of Sciences of USSR-Institute of Philosophy and Sociology, Polish Academy of Sciences.

Harcsa, István 1994. Életmód-életkörülmények a 90-es evekben (Way of life - living conditions in the 90s). Budapest: Central Statistical Office.

Kolosi, Tamás 1984. "Status and Stratification." In Stratification and Inequality, ed. by R. Andorka and T. Kolosi. Budapest: Hungarian Sociological Association.

Kolosi, Tamás 1987. "Latent Dimensions of Status Inheritance." Paper presented at the semiannual meeting of ISA RC 28 Social Stratification, Berkeley. 
Kolosi, Tamás 1990. “The Determinants of Life Style.” Paper presented at the "Social Stratification and Differentiation of Life Styles" session of ISA RC 28 Social Stratification at the XII. World Congress of Sociology, Madrid.

Lenski, Gerhard 1954. "Status Crystallization: A Non-vertical Dimension of Social Status." American Sociological Review 19: 405-413.

Machonin, Pavel 1970. "Social Stratification in Contemporary Czechoslovakia." American Journal of Sociology 75: 725-741.

Mansurov, N. S., V. A. Yadov, Z. Sufin, T. M. Jaroszewski (eds.) 1974. Personal activity in the socialist society. Moscow-Warsaw: Institute of Sociological Research. Academy of Sciences of USSR-Institute of Philosophy and Sociology, Polish Academy of Sciences.

Maslow, H. H. 1954. Motivation and Personality. New York.

Matijù, Petr 1990. "Family Effect on Educational Attainment in Czechoslovakia, the Netherlands and Hungary." Pp. 187-210 in Social Reproduction in Eastern and Western Europe, ed. by J. L. Peschar. Nijmegen: Institute for Applied Social Sciences.

Róbert, Péter 1984. “A Multidimensional Approach to Social Mobility." In Stratification and Inequality, ed. by R. Andorka and T. Kolosi. Budapest: Hungarian Sociological Association.

Róbert, Péter 1990. "The Role of Cultural and Material Resources in the Status Attainment Process: The Hungarian Case." Paper presented at the "Social Stratification and Differentiation of Life Styles" session of ISA RC 28 Social Stratification at the XII. World Congress of Sociology, Madrid.

Róbert, Péter, Matild Sági 1994. "Social background of middle class formation in Hungary." Paper presented at the session "Process of Stratification in Eastern Europe" at the XIII. World Congress of Sociology, Bielefeld, July 18-23.

Siciński, Andrzej 1974. "Style of life in socialist society." Pp. 173-199 in Personal activity in the socialist society, ed. by N. S. Mansurov, V. A. Yadov, Z. Sufin and T. M. Jaroszewski. Moscow-Warsaw: Institute of Sociological Research, Academy of Sciences of USSR-Institute of Philosophy and Sociology, Polish Academy of Sciences.

Siciński, Andrzej (ed.) 1978. Styl życia. Przemiany we wspótczesnej Polsce (Style of life. Transformations in contemporary Poland). Warszawa: Państwowe Wydawnictwo Naukowe.

Sobel, Michael E. 1981. Lifestyle and Social Structure: Concepts, Definitions, and Analyses. New York: Academic Press.

Sobel, Michael E. 1983. "Lifestyle Differentiation and Stratification in Contemporary U.S. Society." In Research in Social Stratification and Social Mobility 2., ed. by D. Treiman and R. V. Robinson. Greenwich: JAI Press.

Szalai, Alexander 1972. The Use of Time. Daily Activities of Urban and Suburban Population in Twelve Countries. The Hague: Mouton.

Szalai, Alexander, Frank M. Andrews (eds.) 1980. "The quality of Life. Comparative Studies." SAGE Studies in International Sociology 20.

Szántó, Miklós 1972. "Free Saturdays and Changes in the Way of Life of Hungarian Industrial Workers Living in Town." Society and Leisure Time 4: 41-53.

Szántó, Miklós (ed.) 1977. Ways of Life. Budapest: Corvina Press.

Utasi, Ágnes 1984. "Life styles, demand levels and Hungary's elite." In Stratification and Inequality, ed. by R. Andorka and T. Kolosi. Budapest: Hungarian Sociological Association.

Veblen, Thorstein 1931. The Theory of the Leisure Class. New York: The Viking Press.

Vitányi, Iván 1978. “An Investigation into Artistic Taste among Workers.” Pp. 267-280 in Hungarian Society and Marxist Sociology in the Nineteenseventies, ed. by Tibor Huszár, Kalmán Kulcsár and Sándor Szalai. Budapest: Corvina Press. 
Weber, Max 1966. “Class, status and party.” In Class, Status and Power, ed. by R. Bendix and S. M. Lipset. New York: The Free Press.

Wesołowski, Włodzimierz 1970. Zróżnicowanie społeczne (Social stratification). Wrocław: Ossolineum.

Wesołowski, Włodzimierz, Kazimierz Słomczynski 1983. "Reduction of Inequalities and Status Inconsistency." Angewandte Sozialforschung 11: 185-194. 